\title{
Sovyet Tehdidine Karşı Güvenlik Arayışları: I. ve II. Menderes Hükümetlerinin (1950-1954) NATO Üyeliği ve Balkan Politikası
}

\section{Dr. Sedef BULUT*}

\section{ÖZET}

İkinci Dünya Savaşı sonrasında ortaya çıkan iki kutuplu dünya düzeni Türkiye'yi de yakından etkilemiştir. Sovyet tehdidine karşı Batı dünyasına yakınlaşan Türkiye, ittifaklar içinde yer almak için büyük çaba göstermiştir. CHP tarafindan başlatılan NATO'ya üye olma girişimleri 1950 seçimleri ile iktidara gelen Demokrat Parti (DP) tarafindan da devam ettirilmiştir. DP iktidarının ilk döneminde(1950-1954) iki hükümet kurulmuş ve dış politikada aktif biçimde Batı'ya dönük bir politika izlenmiştir. DP'nin en önemli icraatı 1952 yılında Türkiye'nin NATO üyeliğini gerçekleştirmek olmuştur. Kore Savaşı sonrasında NATO'ya kabul edilen Türkiye, $A B D$ ve Ingiltere ile olan ilişkilerini daha da geliştirmenin yollarını aramıştır. Bu dönemde Türkiye, Yugoslavya ve Yunanistan ile bir ittifak oluşturarak Balkan Pakı'nın kurulmasını să̆lamış ve Balkanlarda oldukça aktif bir politika izlemiştir. Bu makalede Menderes Hükümetleri döneminde Türkiye'nin NATO üyeliğine girişi ve Balkan Politikası, hükümet programları, TBMM tutanakları ve Ingiliz arşiv belgeleri esas alınarak incelenmiştir

Anahtar Kelimeler: Demokrat Parti, Türkiye'nin NATO'ya girişi, Balkan Paktı, Balkan Politikası.

\section{Security Quests Against Soviet Threat: N.A.T.O Membership} and Balkan Policy of The First and The Second Menderes

\section{Governments (1950-1954)}

\section{ABSTRACT}

The bipolar world order that appeared after the World War II has also influenced Turkey closely. Turkey, approaching Western World against Soviet

\footnotetext{
- Dr. Atatürk İlkeleri ve İnkılap Tarihi Bölümü Okutmanı.
} 
threat, endeavored in order to participate in the alliances. Attempts to affiliate to NATO were begun by People's Republican Party (PRP) and carried on by Democrat Party which came to power with 1950 Elections. In the first period of Democrat Party's rule (1950-1954), two governments were formed and they followed a foreign policy which is actively directed towards Western. The most prominent action of Democrat Party was to actualize Turkey's membership in NATO 1952. Being accepted to NATO after Korean War, Turkey searched for ways to improve her relationships with USA and England further. In this period, Turkey formed Balkan Pact by confederating with Greece and Yugoslavia, and followed a considerably active policy in the Balkans. In this article, Turkey's affiliation to NATO and her Balkan policy during Menderes governments were analyzed grounding on governmental programmes, records of Turkish Grand National Assembly and English archieve documents.

Key Words: Democrat Party, Turkey's affiliation to N.A.T.O, Balkan Pact, Balkan Policy

\section{GİRIŞ}

14 Mayıs 1950 seçimleriyle büyük bir başarı kazanan DP'nin Başvekili sıfatıyla İstanbul Milletvekili Adnan Menderes, hükümeti kurmakla görevlendirilmişti. 22 Mayısta kabineyi ilan eden Adnan Menderes, 29 Mayısta TBMM de hükümet programını açıklamıştır. Programın ilk bölümünde tek parti rejiminin eleştirisine yer verilirken, ikinci bölüm, daha çok özgürlük ve refah konusunda vaatlere ayrılmıştır ${ }^{1}$. Başbakan dış politikada izleyecekleri rotayı ise, şu sözlerle ifade etmiştir." "...Birleşmiş Milletler idealine samimi bağlılığımızı tekrara lüzum görmüyoruz. Ananevi Ingiliz ve Fransız ittifakına ve Birleşik Amerika ile en sıkı dostluk ve işbirliğine dayanan, dostluklarına daima sadık kalan uzak yakın ve büyük küçük bütün milletlerin istiklal ve toprak bütünlüklerine hürmetkâr olan dış siyasetimizin sulhçu mahiyeti bütün dünyaca malumdur”. Başbakan, Hükümetinin dış politikadaki en büyük emelinin ise, Truman Doktrini ve Marshall yardımlarıyla Türkiye'nin barış̧̧ı siyasetini destekleyen Birleşik Amerika ve büyük müttefikler İngiltere-Fransa ile siyasi, iktisadi ve kültürel münasebetleri gün geçtikçe kuvvetlendirmek olduğunu önemle vurgulamıştır. Doğu Akdeniz'de güvenliği maddi ve manevi bakımdan kuvvetlendirmek için büyük dost olarak tanımlanan ABD'nin ve müttefiklerin dikkatini bu bölgeye çekmek de DP'nin hedefleri arasındadır. Diğer yandan Yakındoğu devletleriyle sıkı münasebetler kurarak bu bölgede

\footnotetext{
1 Mehmet Ali Birand, Can Dündar ve Bülent Çaplı, Demirkırat Bir Demokrasinin Doğuşu, İstanbul, 2007, s.55. s. 363-364

Kazım Öztürk, Türkiye Cumhuriyeti Hükümetleri ve Programları, İstanbul, 1968,
} 
emniyetin ve yardımlaşmanın sağlanması ise, son derece lüzumlu görülmekle birlikte bu neticenin aynı zamanda Ortadoğu kadar bütün dünyanın da emniyeti bakımından önemli olduğu vurgulanmaktadır ${ }^{3}$.

Hükümet programında vurgulanan bu esaslar DP'nin gelecekteki icraatlarının adeta habercisi konumunda olmuştur. DP parti programında da dış politika konusunda: " "milletler birliği amacını hedef tutan barış̧̧ı ve açık bir dış siyaset" üzerinde önemle durulduğu görülmektedir. Dışişleri Bakanı Köprülü de Mayıs sonunda Brüksel'de verdiği demeçte:. " Íkinci Dünya Harbinden beri Batı'ya yönelmiş olan diş siyasetimiz son seçimler neticesinde, bu istikamette daha faal bir şekil alacaktır" diyerek DP'nin dış politikası hakkında önemli ipucu vermiştir.

DP genel seçimlerden sonra, aynı yıl içinde yapılan üç yerel seçimden de başarıyla çıkmasına rağmen hükümet içinde artan anlaşmazlıklar istifalara yol açmıştır. Başbakanla anlaşmazlığa düşen Milli Eğitim Bakanı'nın istifasını, Sağlık ve Bayındırlık Bakanları'nın istifaları takip etmiştir. On yıllık DP iktidarı döneminde kurulan hükümetler içinde en kısa ömürlüsü I. Menderes Hükümeti (22 Mayıs 1950-8 Mart 1951) olmuștur. Adnan Menderes tarafından 9 Martta açıklanan İkinci Hükümette (2 Nisan 1951-26 Mayıs 1954), üç yeni bakan görev alırken altı bakanın yeri değiştirilmiştir. Dışişleri Bakanlığı'na Fuad Köprülü yeniden atanmıştır. Yeni Hükümetin programında ise, birincisine göre fazla bir değişiklik yapılmamıştır ${ }^{6}$. Dış politika hususunda da birinci programla paralel görüşlere yer verilmiştir. Hükümet Programında, Birleşmiş Milletler idealine bağlılığı bir kez daha vurgulayan Menderes, ortak bir güvenlik sistemi kuruluncaya kadar hür milletler cephesinde birbirini tamamlayacak ve arada gedik bırakmayacak güvenlik anlaşmaları sayesinde saldırıları önlemenin mümkün olacağını vurgulamıştır. Diğer yandan "büyük dost" olarak tanımladığı ABD ile işbirliğinin her geçen gün daha da geliştiğini ifade eden Menderes, ayrıca İngiltere ve Fransa ile olan mevcut ittifakı da dış siyasetin önemli iki mesnedi olarak addetmiştir ${ }^{7}$.

II. Dünya Savaşından sonra dış politikaya hâkim olan en önemli mesele, Avrupa'yı olduğu kadar Türkiye'yi de tehdit eden Sovyet emperyalizmine

${ }^{3}$ Öztürk, a.g.e., s.363-364

${ }^{4}$ Madde 18- Dış politikamız, milletlerin hukuk eşitliğine, milletlerarası siyasi iktisadi ve kültürel işbirliğine, kolektif güvene, iyi komşuluk münasebetleri esasına dayanmalıdır. Milli varlığın ancak milli kuvvetle korunabileceği kanaatine bağlı kalmakla beraber, milletler birliği gayesini hedef tutacak barışçı ve açık dış siyasetin, millet menfaatlerine en uygun ve realist yol olduğuna inanıyoruz. ( DP Tüzük ve Program, Ankara,1949.s.52.

Feroz ve Bedia Tugay Ahmad, Türkiye'de Cok Partili Politikanın Açıklamalı Kronolojisi 1945-1971, İstanbul, 1976, s.71.

6 Mustafa Albayrak, Türk Siyasi Hayatında Demokrat Parti (1946-1960), Ankara, 2004, s.202,206.

${ }_{7}$ Hükümetin Programı (30.03.1951), Ankara,1951.,s.15-16. 
karşı duyulan güvenlik endişesi olmuştur. Demokrat Parti iktidarının ilk döneminde dış politika açısından oldukça aktif bir dönem yaşanmıştır. Hükümet programlarında da görüldügüü gibi, Batı ile özellikle İngiltere ve ABD ile ilişkileri geliştirmek için büyük çaba sarf eden Menderes Hükümetleri, NATO'ya üye olarak Sovyetlere karşı duyulan bu endişeyi ortadan kaldırmayı hedeflemişlerdi. Ancak Doğu Asya'da Çin Halk Cumhuriyeti'nin ortaya çıkması ve Kore Savaşı ile milletlerarası komünizmin geniş bir alanda tehlike yaratması gibi gelişmeler Türkiye'yi, kendi güvenlik sistemini güçlendirmek durumunda bırakmıștır. Bu gelişmelerin etkisi altında Türkiye, Balkan ve Bağdat Paktlarının oluşmasında aktif rol oynamıştır ${ }^{8}$.

Bu makalede, Demokrat Parti iktidarının ilk dönemi (1950-1954) özellikle dış politika faaliyetleri açısından ele alınmıştır. Dış siyaset açısından oldukça hareketli olan dönemin göze çarpan en önemli gelişmeleri; Kore Savaşı ve Türkiye'nin NATO 'ya üye olmasıdır. Ancak bu süreçte Türk dışişlerini en çok meşgul eden konulardan birisi de Balkanlardır. Balkan cografyasında ortaya çıkan gelişmeler Türkiye ve müttefikleri tarafından yakından izlenmiştir. Menderes, Balkan Paktının kurulmasına büyük önem vermiş, Türkiye Paktın kurulmasına öncülük etmiştir. Türkiye ile İngiltere arasındaki yakınlaşma da dönemin dikkat çekici gelişmelerindendir. ABD'den sonra, Ingiltere ile olan ilişkileri geliştirmek hususunda yoğun bir çaba harcayan Türk Hükümeti, 1952 yılı itibarıyla İngiliz Başbakanı Churchill'in Türkiye'yi ziyaret etmesi için diplomatik girişimlerde bulunmuştur. Söz konusu döneme ait gelişmeler İngiliz arşiv belgeleri ekseninde değerlendirilmiştir. İngiliz hükümetinin Türkiye hakkındaki görüşlerine, Balkanlar ve Ortadoğu konusunda ki Türkiye'den beklentilerine bu belgeler doğrultusunda yer verilmiştir. Türkiye'nin NATO üyeliği sonrasında Balkanlarda yürüttügü aktif politika bu çalışmanın eksenini oluşturmaktadır. Kıbrıs meselesi ve Ortadoğu'daki gelişmeler yoğun olarak Demokrat Patinin ikinci döneminde (1954-1957) gündemi oluşturmuştur. Bu nedenle Kıbrıs ve Ortadoğu ile ilgili konulara makale içinde sınırlı olarak yer verilmiştir.

\section{DP İktidarı ve TÜRKIYYE'nin NATO Üyeliği}

II. Dünya Savaşı sonrasında Sovyetler karşısında yalnız kalan Türkiye'ye ilk desteği ABD göstermiştir. Missouri zırhlı gemisinin 5 Nisan'da İstanbul'a gelişi ve ABD'li kumandanların Milli Şef İnönü'yü ziyaret etmeleri Türk- Amerikan ilişkileri açısından önemli bir adımdır. Görkemli törenlerle karşılanan Amerikan filosunun ziyareti basında da geniş yer bulmuş ${ }^{9}$ ve filonun gelişi "Türk-Amerikan dostluğunun parlak bir

${ }^{8}$ Fahir Armaoğlu, 20. yüzyıl Siyasi Tarihi (1914-1980), Ankara, 1993, s. 517.

9 Ayrıntılı bilgi için bkz. Cumhuriyet, 5-10 Nisan 1946. 
ifadesi" olarak değerlendirilmiştir. Truman'ın özel temsilcilerinden Weddell de yaptığı açıklamada Missouri ile Amerika ve Türkiye arasındaki dostluğu sembolize etmek için geldiklerini ifade etmiştir ${ }^{10}$.

Truman Doktrini ve Marshall Planı çerçevesinde gelen yardımlarla birlikte Türkiye ABD çizgisine doğru yönelme gösterirken mevcut tablo DP iktidarı döneminde daha da belirginleşmiştir. Esas itibariyle 1950'li yıllarda bu politika hususunda CHP ve DP uyum içerisindedir. Bu politikanın ortak noktalarını ise, her türlü sol faaliyete karşı olmak, Sovyet karşıtı tutum izlemek, ABD'nin politik çizgisini takip etmek şeklinde sıralamak mümkündür ${ }^{11}$. 14 Mayıs 1950'ye yani DP'nin yönetimi ele almasına kadar Türkiye'nin NATO içerisinde yer alması konusu daha çok bir arzu olmaktan öteye gitmemiştir. Türkiye NATO'nun henüz kuruluş aşamasında kendisinin bu paktın dışında bırakıldığını öğrenmiş ve hiç olmazsa Akdeniz Paktı gibi bölgesel bir pakt içerisinde ABD ile beraber olmak istemiştir ${ }^{12}$. Türkiye'nin NATO üyeliği hususunda en çok itiraz edenler, başta İngiltere olmak üzere Norveç, Danimarka, Hollanda ve Belçika'dır. İngiltere'nin itirazının ardındaki en büyük neden Ortadogu'daki çıkarlarıdır. Sovyetlerin Ortadogu üzerindeki emellerini kendisi açısından büyük bir tehdit olarak algılayan İngiltere, Ortadoğu'ya yerleşmenin yolunu aramaktaydı. Bu politika çerçevesinde İngiltere ancak Ortadoğu savunma sistemine katılması şartı ile Türkiye'nin NATO üyeliğini desteklemeye karar vermiştir. Hollanda, Belçika, Danimarka gibi devletler ise, Sovyet tehdidine yoğun bir şekilde maruz kalan Türkiye'nin NATO'ya katılmasına karşılık Sovyetlerin sert bir tepki göstermesinden çekinmiş ve bunu bir güvenlik sorunu olarak değerlendirmişlerdir ${ }^{13}$. Türkiye'nin NATO'ya alınması hususunda en büyük itiraz başlangıçta İngiltere'den gelmişti. Yukarıda da ifade edildiği gibi, İngiltere, Türkiye'yi her şeyden önce bir Ortadogu savunma düzenine sokmak istemiştir. Ancak 1951 yazına doğru Ortadogu'daki siyasi havanın gergin bir hal alması ve İran bunalımının doğurduğu tedirginlik de ${ }^{14}$

${ }^{10}$ Cumhuriyet, 6 Nisan 1946.

${ }^{11}$ Tevfik Çavdar, Türkiye'nin Demokrasi Tarihi, Ankara, s.2004

${ }_{12}$ Mustafa Ekincikli, Türk Dış Siyaseti Inönü-Bayar Dönemleri, Ankara, 2007,s. 174.

${ }_{13}$ Armaoğlu, a.g.e, s.519.

${ }_{14}$ 1951-54 yılları arasında ortaya çıkan İngiliz-Iran petrol anlaşmazlı̆̆ı bugüne kadar devam eden Körfez petrolleri ve Batı meselesinin başlangıcın teșkil etmistir. Bu meselenin ortaya çıkış Sovyetlerin Iran üzerindeki baskılarından beş yıl gibi kısa bir süre sonra ortaya çıkması bakımından da önemlidir. İran petrollerini işleten Anglo-İranian Oil Company adlı Ingiliz șirketi ile en son anlasma 1933'te imzalanmıstt. II. Dünya Savasından sonra ödenen paranın arttırılması gerekçesiyle, Iran hükümeti anlaşmanın değiștirilmesini istemistir. Ancak Meclisteki Milli cephe grubu ile lideri Dr. Musaddık, İran petrollerinin devletleștirilmesini savunmus ve anlaşmaya karş çımıștır. Iran Milli Meclisi, 1949'da anlasmayı tasdik etmeyip reddetmiştir. Bu gelişme üzerine tüm Iran'da petrollerin millileștirilmesi için gösteriler yapılırken, bu gelişmeler Komünist Tudeh Partisi ile aşırı să̆cı Molla Kaşani tarafından da desteklenmistir. Musaddık'ın 1951 yılında başbakanlı ăa getirilmesiyle birlikte aynı yıl Meclis. petrollerin millileştirilmesini öngören kanunu kabul etmiştir. Bu gelişmenin ardından Ingiltere meseleyi bir yandan Milletlerarası Adalet Divanına götürürken, diğer yandan da 
NATO'nun genişletilmesi konusunda özellikle İngiltere'nin itirazlarını önemli ölçüde zayıflatmıştır. 18 Temmuz 1951'de İngiliz Dışişleri Bakanı Morison Avam Kamarası'nda yaptığ 1 bir konuşmada Türkiye ile Yunanistan'ın üyeliğinin destekleneceğini açıklamıştır. Bu konuşmada açıkça İngiliz Hükümeti, Yunanistan ve Türkiye NATO'ya alındığı takdirde, bu iki devletle birlikte İngiltere ve Fransa'nın da dâhil olduğu bir Ortadoğu savunma teşkilatının NATO'ya ek olarak kurulmasını istemiştir ${ }^{15}$.

İkinci Dünya Savaşı sonrasında zor bir dönem yaşayan Türkiye için NATO üyeliği önemli bir çıkış yolu olarak görülmüştür. DP'nin iktidara gelir gelmez NATO üyeliği ve Amerika'nın yanında olmayı bir hedef haline getirmelerinde Türkiye'nin maruz kaldığ $\breve{g}_{1}$ Sovyet baskısı ve duyulan güvenlik endişesi kadar, bunun kendileri için önemli bir iç politika malzemesi olması da etkili olmuştur. DP liderleri, 1950 seçim kampanyası sırasında yaptıkları konuşmalarda NATO'ya katılmayı aynı zamanda demokratik düzenin geleceğini güvence altına almak için de kaçınılmaz bir teşebbüs olarak görmüşlerdir ${ }^{16}$. Menderes Hükümetinin oldukça radikal bir kararla Kore'ye asker göndermesi ülke çapında büyük yankılar uyandırmıştır. Genel olarak bu teşebbüs, kamuoyunda olumlu karşılanmakla beraber CHP bu kararı biçimsel olarak eleştirmiş, TBMM onayına sunulmadan yurtdışına asker gönderilmesini bir Anayasa ihlali olarak tanımlamıştır. Kore Savaşı'na katılma kararına en şiddetli tepki ise Behice Boran'ın başkanlığını yaptığı Barışseverler Derneği'nden gelmiştir. Bu kararı bir bildiri ile protesto eden dernek, askeri mahkemece takibata uğramış ve kapatılmış, yöneticileri ise, on beş ile on ay arasında değişen cezalara çarptırılmıştır ${ }^{17}$. Barışsever Cemiyeti üyelerinin hapis cezasına çarptırıldığı kararda ise şöyle denilmektedir: "Cemiyet gayesinin siyasi

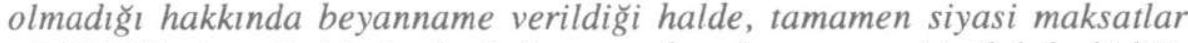
güdüldü̆̈̈̈, Amerikalılarla dostluğumuzun bozulması gayesi istihdaf edildiğ i, Kore'ye hükümetin asker gönderme kararı karşısında neşrettikleri

Iran'a kruvazör ile bir miktar asker göndermiş ancak 1921 Sovyet-Iran anlaşmasına göre işin içine Sovyet Rusya'nın karısabileceği düsüncesiyle fazla ileri gitmemistir. 1952 Mayıs seçimlerinde Dr. Musaddık'n Milli cephesi ve Tudehçiler çoğunluğu elde edince Iran'da siyasi yönden ciddi gelişmeler olmuştur. Şah tahttan feragat etmek zorunda birakularak yurtdısına kacmıstır. Komünist Tudeh partisinin gittikçe güclenmesi üzerine 1953 'te General Zahidi liderliğinde ordu darbe yapmıs, Şah ülkesine geri dönmüstür. Başbakanlı̆̆a getirilmiş olan General Zahidi, petrol anlaşmazlığının çözü̈mü için Amerikanın aracıllı̆̆ını istemiş ve Anglo İranian Oil Company ile Amerikan petrol sirketleri ve Iran hükümeti arasinda Ağustos 1954 yılında bir anlaşma imzalanmıştır. Ayrıntılı bilgi için bkz. Armaoğlu, a.g.e,s 489-491.

${ }_{15}$ Mehmet Gönlübol vd.( kolektif eser), Olaylarla Türk Dış Politikası (1919-1990), Ankara, 1993,s. 231.

${ }^{16}$ Ekincikli, a.g.e.s., s. 204

${ }^{17}$ Barışseverler derneğinin genel sekreterliğini Adnan Cemgil yapmıştı. Yönetim kurulu üyeliklerinde ise Nevzat Ozmeriç, Reşat Sevinçsoy, Vahdettin Barut, Fuat Toprakoğlu ve Muvakkar Güran bulunuyordu. Çavdar,a.g.e,s.36. 
beyannamelerle halkın hükümete itimadını kırdlkları ve milli mukavemeti zaafa uğrattıklarl zikredilmektedir ${ }^{18 "}$.

İstanbul, Ankara, İzmir'de kararı eleştiren yazı ve karikatürler yayınlayan on yedi mizah dergisi de komünist oldukları gerekçesiyle kapatılmışıır ${ }^{19}$.

Kore'ye asker gönderme kararı, Anayasa'ya aykırılık iddialarının dışında Cumhuriyet tarihinin istisnai durumlarından birisi olması dolayısıyla da büyük önem arz etmektedir. Bu tarihe kadar Türkiye, Misak-1 Milli sınırları dışında bir askeri harekâta ya da müdahaleye katılmaktan kaçınmıştır. Türkiye'den binlerce kilometre uzaklıktaki Kore Savaşı aynı zamanda hükümetlerin dış politika eylemlerinin TBMM'de tartışılması dönemini başlatmıştır ${ }^{20}$. Millet Partisi'nin tek milletvekili Kırşehir Milletvekili Osman Bölükbaşı ve Mardin Bağımsız Milletvekili Kemal Türkoğlu'nun Kore'ye gönderilen savaş birliği hakkında Başbakan'a gensoru açılmasına dair verdikleri ortak önerge mecliste yogun bir biçimde tartışılmıştır. Söz konusu önergede adı geçen iki milletvekili, bir emrivaki ile tatbik edilen bu kararın geri alınabileceğini asla düşünmediklerini ifade etmekle birlikte, Anayasa'ya aykırı bir karar alan mevcut hükümetin işbaşında kalamayacağını ifade etmiştirler. Milletin gerçek temsilcilerinin Milli hâkimiyet haklarını çiğnetmek gibi ağır ve tarihi bir mesuliyeti omuzlarına alamayacağı ifade edilen önerge karşısında hükümet adına çoğunlukla Adnan Menderes cevap vermiştir ${ }^{21}$. Bu önergeye karşılık, İstanbul Milletvekili Mükerrem Sarol ve yedi arkadaşının Birleşmiş Milletler emrine Kore'ye silahlı kuvvetler gönderilmesi hususunda Hükümet tarafından verilen hukuki ve siyasi izahatın tasvip edilmesi yönünde verdikleri önerge ise, 11 Aralık günü oylanmış ve oyçokluğu ile kabul edilmiştir. Hükümete verilen bu itimat oyu neticesinde Mecliste teşekkür konuşması yapan Adnan Menderes, bu kararın gayrı meşru olmadığının en yetkili makam olan TBMM tarafından onaylanmasının memnunluk verici olduğunu ifade ederek bundan sonra memleket zararına olan bu çeşit "zehirli propagandaların" durmasını temenni etmiştir ${ }^{22}$.

Menderes Hükümetinin aldığı bu tarihi kararın ardından İngiltere, Yeni Zelanda ve Avusturalya da Kore'ye asker göndermişlerdir ${ }^{23}$. Yaklaşık üç yıl

\footnotetext{
${ }^{18}$ Feroz ve Bedia Tugay Ahmad,a.g.e.,s. 78 Naklen; Cumhuriyet 31.12.1950.

${ }_{19}$ Türk Diş Politikası, Kurtuluş Savaşından Bugüne Olgular, Belgeler, Yorumlar 19191980 (Edt. Baskın Oran) C.1 İstanbul, 2003, s.546.

${ }_{20}^{20}$ Türk Diş Politikast...,., s.547.

199. Ayrntılı bilgi için bkz. TBMM Tutanak Dergisi, Dönem IX, c 3, 11.12.1950. s.136-

22 Yapılan oylama neticesinde 311 kabul oyu verirken, 39 red oyu verilmiş 1 üye çekinser kalmıştır. TBMM Tutanak Dergisi, ..., s.198-201.

${ }_{23}$ Hüseyin Bağcı, DP Dönemi Dış Politikası, Ankara, 1990, s. 27.
} 
süren savaş sonucunda Türkiye yüzlerce şehit vermiştir. ${ }^{24}$ NATO'ya üyelik girişimleri hususunda inisiyatifi bizzat ele alan Cumhurbaşkanı Celal Bayar, çeşitli ülkelerde görev yapan büyükelçilerin görüşlerini aldıktan sonra hükümete direktif vermiş, NATO üyesi ülkelerin Ankara'daki büyükelçilerine Türkiye'nin bu konudaki kararlılığını ısrarla anlatmalarını istemiştir. 1951 yılı başlarında Türkiye'ye gelen yüksek seviyede sivil askeri bir Amerikan heyeti ile bizzat görüşmeler yapan Bayar, kısa bir süre sonra kendisi ile görüşmeye gelen ABD dışişleri Bakanı muavinlerinden McGhee'ye, “Türkiye'nin Bat dünyasının yanında olmakla Sovyetlerin husumetine maruz kaldı ̆̆ını ancak birlikte hareket etmek istediği bloğun teminatından mahrum olmanın, Türkiye'nin razl olaca $\breve{g}_{l}$ bir durum olmadığını" ifade etmiştir ${ }^{25}$. Bayar, İngiltere Büyükelçisi Noel Charles ve İngiltere'nin Ortadoğu kuvvetleri başkumandanı General Sir Brian Robertson ile de görüşmelerde bulunmuştur. Bu hususta Dışş̧leri Bakanı Fuat Köprülü de yoğun bir faaliyet göstermiş, “Türkiye'nin NATO'suz, NATO'nun da Türkiyesiz olamayacağı" fikrini kabul ettirmeye çalışıştır. Köprülü, Kore Savaşı'nı, Türkiye'nin ve Türklerin insani değerlere ve demokrasiye ne kadar önem verdiğini dünyaya ispatlayacak iyi bir fırsat olarak görmüştür. Ona göre; Türkiye bu fırsatı iyi değerlendirmiş ve NATO'ya giriş yolunu açmıştır. İnsanlığa, hukuka ve barışa büyük katkılar sağlamış olan Türk milletinin, demokrasi ve barışın korunması için kurulan NATO'ya girmesi doğal bir sonuçtur ${ }^{26}$.

DP Hükümeti, Kore'ye asker göndermesi neticesinde Türkiye'yi Kuzey Atlantik Paktına sokmayı başarmıştır. 16 Şubat 1952 'de ABD elçisinin on iki devlet adına sunduğu davetiye ile Türkiye Lizbon'da Konferansa çağrılmış 19 Şubat 1952 'de ise, TBMM iktidar ve muhalefetteki milletvekillerinin oybirliği ile Türkiye'nin NATO üyeliğini onaylamıştır ${ }^{27}$. Adnan Menderes NATO'ya katılma münasebetiyle Mecliste yaptığı konuşmada, bu hadiseyi tarihi bir gün olarak nitelendirmiş, ortaya çıkan sonucun bir birlik-tesanüt manzarası ve azmi kararla tecelli ettirilmiş

${ }^{24}$ Kore'ye ilk aşamada 4500 asker gönderilmiştir. Bu birlikler Albay Tahsin Yazıcı Komutasında, 25. Amerikan Tümenine bağlı olarak görev almıştır. Savașın ilerleyen aşamalarında ise, asker sayısı 6000'in üzerine çıkmıştır. 27 Temmuz 1953 'te imzalanan ateşkese kadar Türk askerlerinden $721^{\prime} \mathrm{i}$ şehit olurken 672'si yaralanarak geri dönmüş, 1475 yaralı asker Kore'de tedavi edilmiş, 234 asker esir düşerken 175 kişi kayıp olarak bildirilmiştir.

(Türk Dıs Politikası...,s.547.) Mustafa Albayrak bu sayıyı 937 ölü ve 2068 yaralı ve 228 esir olarak verirken ABD elçisi George Mc Ghee'nin ise, bu kayıpları 706 ölü, 2.111 yaralı, 168 kayıp ve 219 tutsak olarak bildirdiğini söylemektedir bkz. Mustafa Albayrak, a.g.e., s. 416 .

Ayrıntılı bilgi için bkz. Mehmet Saray, Sovyet Tehdidi Karsısın da Tükive'nin NATO'ya Girişi III. Cumhurbaşkan Celal Bayar'in Hatıralart ve Belgeler, Ankara, 2000, 99113.

${ }^{26}$ Saray, a.g.e., s.114-115.

${ }^{27}$ Cem Eroğul, DP Tarihi ve Ideolojisi, Ankara, 2003, s.116 
olduğunu vurgulayarak, gerçekleştirilmiş olan dayanışmanın hiçbir sebeple gölgelenmemesi gerektiğini söylemiştir. Türkiye'nin NATO'ya kabulünü, Türk milletinin ve onun iradesinin temsilcisi olan bir meclisin eseri olarak niteleyen Menderes, bu sebeple Hükümete teşekkür edilmesini gereksiz olarak değerlendirmiştir ${ }^{28}$.

Türkiye'nin NATO'ya üye olmak için yaptığı bütün girişimler en başından beri Sovyetler tarafından yakından izlenmiş ve engellenmeye çalışılmıştır. Sovyet hükümeti yalnızca resmi kanallar değil aynı zamanda basın yoluyla da Türkiye'ye yönelik ağır ithamlarda bulunmuştur. NATO ve müttefiklerine yönelik bütün bu olumsuz propagandalara Stalin bizzat destek vermiştir. Stalin, Sovyet Komünist Partisi'nin 5 Ekim 1952 tarihli XIX. toplantısında başta ABD olmak üzere diğer NATO üyelerini Sovyetlere karşı blok oluşturmakla suçlayarak bu düşmanca hareketin dağıtılacă̆ını söylemiştir ${ }^{29}$. 5 Mart 1953'te Stalin'in ölümü ve Nikita Khruşçev'in liderliği ile Türk- Sovyet ilişkileri yeni bir döneme girmiştir. Sovyetler 30 Mayıs 1953 'te yapılan yazılı açıklama ile her ne kadar "Türkiye'den toprak talebinde bulunmaktan ve Boğazların ortak savunması hakkındaki görüşlerinden vazgeçtiklerini" ifade etseler de Boğazlar üzerindeki talepleri belirsiz kalmıştır. Dolayısıyla görünürdeki bu yumuşama, inandırıcılıktan ve güvenilirlikten uzak olarak değerlendirilmişti ${ }^{30}$.

\section{Türk-İngiliz İlişkilerinde Gelişme ve Balkan Paktına Doğru}

İkinci Dünya Savaşı'nın sonundan itibaren, kendi güvenliğini Batı'ya katılmakta gören Türkiye'nin bu politikası, DP iktidarı tarafından da en yoğun şekliyle devam ettirilmiştir. Türkiye'nin NATO üyeliği dış politikada oldukça aktif bir dönem açmıştır. Sovyet tehdidinin artması üzerine Batı'ya iyice yönelen DP iktidarının ilk yıllarında Türk dışişlerini en çok meşgul eden konulardan birisi de Balkanlardır. Bu dönemde Türkiye, Yunanistan ile anlaşarak Yugoslavya'yı dolaylı yoldan NATO'ya bağlayacak bir ittifak oluşturma konusunda olağanüstü bir çaba göstermiştir ${ }^{31}$.

1948 yılı itibarıyla Sovyetler ile Yugoslavya arasındaki gerginlik ve Yugoslavya'nın Sovyet blogundan uzaklaşması Batılı devletlerin Yugoslavya ile yakından ilgilenmelerine neden olmuştur. Yugoslavya'nın siyasi rejimine karşı duydukları bütün şüphelere rağmen bu devleti kendilerine bağlamak için çaba göstermişlerdir. İki Balkan ülkesi Yunanistan ve Türkiye'nin NATO'ya kabul edilmesinden sonra ise bu ülkeler ile Yugoslavya arasında bir Balkan Paktı kurulması suretiyle bu

${ }^{28}$ Faruk Sükan, Başbakan Adnan Menderes'in Meclis Konuşmaları, TBMM 1950-1960, Ankara,1991,s.117-118.

${ }_{20}$ Saray, a.g.e, s.135-137.

${ }^{30}$ Armaoğlu; a.g.e., s. 521. s.122.

${ }^{31}$ Geçiş Sürecinde Türkiye (Der. Irvin C. Schick, E. Ahmet Tonak),İstanbul, 2003. 
amacın gerçekleştirilebileceği düşünülmüştür ${ }^{32}$. Türkiye ile Bulgaristan arasındaki uzun kara sınırı ve Türkiye'nin Bulgaristan karşısındaki -coğrafyanın niteliğinden kaynaklanan- stratejik zayıflığ $\mathrm{da}^{33}$ Türk hükümetini Balkanlarda işbirliğine itmiştir. Benzer tehditlerle karşı karşıya bulunan ve hızla Batı'ya doğru yaklaşan Yugoslavya ile ittifak yapmak düşüncesi önem kazanmıştı ${ }^{34}$. Kuzey komşuları tarafından destek görmüş bir iç savaştan henüz çıkan Yunanistan'ın, Bulgaristan ile yaşadığı sınır problemleri ve Sovyetler tarafından desteklenen Arnavutluğun yaratacağı tehlike de Yunan yöneticilerini endişelendirmiştir. Bu bakımdan savaş öncesinde olduğu gibi Arnavutluk ve Bulgaristan'a karşı Türkiye ve Yugoslavya istenen denge ve güvenliği sağlayabilird ${ }^{35} .1948$ yılından sonra Yugoslavya'nın durumu, uluslararası dikkati üzerine toplamakla birlikte Yunanistan ile ilişkileri, Yunan iç savaşı sırasında komünist çetelere yaptı̆̆ı yardımlar yüzünden oldukça gergindi. Yugoslavya'nın Sovyet Komünformu'ndan ${ }^{36}$ ayrıldıktan sonra Batılı devletlere özelikle ABD'ye yaklaşması ve yardım almaya başlamasıyla birlikte Batı ile olan ilişkiler düzelmiştir. Bu durum Yunanistan ile olan gerginliği de azaltmıştır. İki devlet arasında bir yumuşamanın görülmesinde, ABD'nin teşvikleri kadar Sovyetlerin Makedonya'da Yunan, Yugoslav toprakları üzerinde bağımsız bir devlet kurma yönünde yürüttüğ̈̈ çalışmaların da etkili olduğunu söylemek mümkündür ${ }^{37}$. Ortadoğu meselesinin de yoğun bir biçimde gündemde olduğu Ekim 1951'de Amerikan, İngiliz ve Fransız Genelkurmay Başkanları Ortadoğu konusunu hükümetle görüşmek için Türkiye'ye bir ziyaret yapmışlardır. İngiltere, Süveyş kanal bölgesinin boşaltılması konusunda Mısır ile anlaşmazlık halinde olduğu için kendilerinin bu bölgede kalmalarına yardımcı olacak bir Ortadoğu Paktı'nın kurulmasında Türkiye'nin önderlik etmesini istiyordu ${ }^{38}$.

Menderes bir yandan Ortadogu'da ABD'nin ve İngiltere'nin yardımlarıyla aktif bir siyaset yürütürken diğer yandan da Atlantik'ten

${ }^{32}$ Eroğul, a.g.e. s.119

33 Bulgaristan'in 1950-1951 yılları arasında ülkesindeki Türkleri göç ettirme politikası endişe uyandırmış ve Sovyetlerin baskı politikasının bir sonucu olarak yorumlanmıştır. Türkiye'nin NATÓ'ya katılması Bulgaristan tarafından da tepkiyle karşılanmıştır. Bu olaylar iki ülke arasındaki ilişkilerin karşılıklı şüphe üzerine gelişmesine neden olmuştur. Rıfat Uçarol, Siyasi Tarih,İstanbul,1985. s.553.

34 Oral Sander, Balkan Gelişmeleri ve Türkiye (1945-1965), Ankara,1969,s.85.

${ }_{35}^{35}$ Sander, a.g.e.s. 86 .

${ }^{6}$ Komünform (Komünist Enformasyon Bürosu), 1947'de Polonya'nın Wilcza Gora kentinde SSCB, Bulgaristan, Macaristan, Çekoslavakya, Polonya, Romanya, Yugoslavya, Fransa ve İtalya komünist partilerinin katılımıyla kurulmuştur. Hedefi, Avrupa'daki tüm parti faaliyetlerini eşgüdümlü hale getirmekti. SSCB ile Yugoslavya arasındaki gerginlik neticesinde 1948 Haziranında Yugoslav Komünist Partisi Kominform'dan çıkarılmıştır. Komünform 17 Nisan 1956'da SSCB tarafından dağıtılmıştır. Ayrıntılı bilgi için bkz. Türk Dıs Politikası..., s.500.

${ }^{37}$ Gönlübol,a.g.e,s. 233

${ }^{78}$ Feroz ve Bedia Tugay Ahmad, a.ge.,s.89. 
Pakistan'a kadar olan güvenlik zincirini tamamlamak için Balkan Paktı'nın kurulmasına büyük önem vermiştir. Menderes'e göre, Türkiye'nin jeopolitik önemi Türkiye'yi otomatik olarak Güney Akdeniz'in doğal lideri olma konumuna getirmektedir ${ }^{39}$. Esas itibariyle Balkan ülkeleri arasında işbirliği denemeleri yeni ortaya çıkmış bir durum değildir. Türkiye, Atatürk döneminde de Balkan politikalarına büyük önem vermiş ve revizyonist faaliyetlere karşı Balkanlarda güvenliği sağlayabilmek için bir Balkan ittifakı kurulmasına öncülük etmiştir ${ }^{40}$. Görünürdeki benzerliğe rağmen 1934 tarihli Balkan Antantı ile 1954 tarihli Balkan İttifakı esasen farklı şartların etkisi altında ortaya çıkmıştır. 1934 tarihli Balkan Antantı çok kutuplu bir sistemde, taraf devletlerin revizyonist devletlerin yarattığı tehdit karşısında işbirliği ile oluşturulmuştur. ABD desteği ve NATO'nun askeri stratejileri gereği kurulan 1954 ittifakı ise, iki kutuplu soğuk savaş döneminin eseridir. ${ }^{41}$.

Türkiye açısından değerlendirildiğinde, Yugoslavya ile herhangi bir mesele bulunmamakla birlikte bu devletin Demirperde'den ayrılması Balkanlar'daki güç dengesi ve kendi güvenliği için faydalı görülüyordu ${ }^{42}$. Yunanistan ile olan ilişkiler ise, NATO üyeliği ile birlikte bir yumuşama dönemine girmişti. NATO'ya girmek için ortak çaba gösteren Türkiye ve Yunanistan bu dönemde birbirine oldukça yaklaşmıştır. Bu yakınlaşma neticesinde karşılıklı olarak diplomatik ziyaretler birbirini izlemiştir. 1952 Ocak ayında Yunan Dışişleri Bakanı'nın Türkiye ziyareti Adnan Menderes ve Fuat Köprülü tarafından iade edilmiş, ardından Yunan Kral ve Kraliçesinin ziyaretleri ertesinde Celal Bayar'ın Yunanistan ziyareti gerçekleşmiştir ${ }^{43}$. Yunan Kralı I. Paul ve Kraliçe Frederika'nın ziyaretleri esnasında Türk-Yunan dostluğunun önemi üzerine bir konuşma yapan Celal Bayar müşterek sınırdan, ideal birliğine kadar iki ülke arasındaki dostluğun daha da faal bir hal almasının günden güne daha da zorunlu hale geldiğini vurgulamıştır. Bayar'a göre bundan böyle bu dostluk her iki memleket içinde

39 Bağcı, a.g.e., s. 54.

${ }^{40}$ Bu amaçla Balkan Antantı, Atina'da 9 Şubat 1934'te Yunanistan, Yugoslavya, Türkiye ve Romanya dışişleri bakanları tarafından imzalanmıştı. Antlaşma Balkanlardaki sınırları bölgedeki revizyonist devletlere karşı korumakla beraber barışın güçlendirilmesi için de yardımı öngörüyordu. 1934-1936 yılları arasında Türkiye, sadece Balkan ülkeleri ile ittifakın Balkanlar'daki statükoyu korumaya yeterli olmadığını fark ettiği noktada, Avrupalı devletlerle de işbirliğine girerek bölgesel paktların oluşması için gayret göstermiştir. Türkiye, İtalya'nın yayılmacılığına karşı bir tedbir olarak gördüğgi Balkan Antantı'nı yaşatmak için büyük çaba göstermiştir. Ancak gerek İtalya'nın antantı bozmak için uyguladığı manevralar gerekse de Almanya'nın Balkanlardaki ekonomik etkisi Balkan devletlerini bu iki devlete yakınlaştırmıştır. Bütün bu gelişmelerle birlikte Yugoslavya'nın 1937'de Bulgaristan ile dostluk Antlaşması yapması da Balkan Antantı'nın 1940 yılında dağılmasına yol açan önemli etkenlerden birisi olmuştur. E. Semih Yalçın, Atatürk'ün Milli Dış Siyaseti, Ankara, 2000 s.225-226.

${ }_{41}$ Türk Dis Politikası,...s.588.

${ }^{42}$ Ekincikli, a.g.e.,s.282.

43 Armaoglu, a.g.e., s.522. 
milli bir siyaset olmuştur ${ }^{44} .27$ Aralık'ta Yunanistan'ı ziyaret eden Celal Bayar yogun bir diplomatik faaliyet yürütürken her fırsatta Türk-Yunan dostlugunun önemini ön plan çıkaran konuşmalar yapmıştır. Coğrafi konumu dolayısıyla her iki ülkenin varlıklarını ve bağımsızlıklarını koruyabilmeleri için ittifaklarının şart olduğunu birçok kez belirten Bayar, Türk-Yunan işbirliğini tarihe kaydedilmiş asrın en güzel eserlerinden birisi olarak nitelendirmektedir. Bayar bu görüşünü ise, şu sözlerle ifade etmiştir: ${ }^{45}$ "Kardeş kavgası diye tavsif edebileceğimiz bir harpten hemen sonra başlayan bu muazzam eserin arz ettiği manzaradan daha muhteşem ve heyecan verici bir şey tasavvur edilebilir mi?". Yapılan bu ziyaretler, üç devlet arasında karşılıklı işbirliği konusunda beliren eğilimi daha da kuvvetlendirmiştir.

Genel olarak değerlendirilecek olursa, bir Balkan ittifakı kurulmasındaki en büyük etken Balkan hükümetlerinin Doğu ile Batı arasındaki Soğuk Savaş mücadelesinden etkilenmiş olmalarıdır. Bunun yanı sıra Türkiye ve Yunanistan'ın NATO'ya girmesi ile Kuzey Atlantik bölgesinden başlayıp büyük bir yay çizerek İran'a kadar uzanan şerit, SSCB'ye karşı güçlü bir savunma hattı haline gelirken aradaki tek açık bölge olarak Yugoslavya'nın kalması da bu yöndeki faaliyetlerin ortaya çıkmasında önemli bir nedendir ${ }^{46}$. Normal şartlar altında siyasi rejimleri birbirinden farklı üç ülkenin, demokratik Türkiye, Komünist Yugoslavya ve Krallık Yunanistan'ın birbirine bu kadar yakınlaşması beklenilmezken, yoğun diplomatik faaliyetler neticesinde bir araya gelen üç Balkan ülkesinin ortak noktası Sovyetler'in Balkan ülkelerini kontrol altına alabileceği endişesidir. Bu endişe ise, ortak güvenlik çıkarlarına sahip bu üç ülkeyi bir araya getirerek Pakt'ın kurulması için gerekli olan sürecin hızlanmasına neden olmuştur. Yugoslavya Devlet Başkanı Mareşal Tito ideolojik farklılıklara rağmen ortaklaşa bir güvenlik ittifakının gerekliliğinin farkındaydı. Bu durumu 7 Aģustos 1952'de Belgrad'ı ziyaret eden Türk delegasyonuna hitaben yaptığı şu açıklama ile ortaya koyuyordu: ${ }^{47}$ "Illişkiler öyle bir noktaya gelmiştir ki, yalnız siyasi ve ekonomik değil, aynı zamanda askeri işbirliği de düşünülebilir".

Sovyetlerin ve ona bağlı Balkan devletlerinin bu coğrafyadaki politikaları Yunanistan, Yugoslavya ve Türkiye'yi bir araya getiren önemli etkenlerden birisi olarak değerlendirilmektedir. Ancak bununla birlikte bu üç ülke ekonomik kalkınmalarını sağlamak için ABD'den gelecek maddi yardıma ihtiyaç duyuyorlardı. Bu sebeple, NATO'nun savunma stratejisini

${ }^{44}$ Celal Bayar'ın Söylev ve Demeçleri 1933-1955, İstanbul, 1999.s.85.

${ }^{45}$ Celal Bayar'm..., s.86.

46 Erol Mütercimler, Mim Kemal Öke, Düşler Ve Entrikalar-DP Dönemi Türk Dış Politikası, İstanbul,2004. s.302.

${ }^{47} \mathrm{Bağcl}$,a.g.e.,s. 55-56. 
güçlendirecek bir Balkan Paktı'nın Batı'dan gelecek askeri ve ekonomik yardımı arttırabileceği beklentisinin de bu birlikteliģin oluşmasında etkili olduğu göz önünde bulundurulması gereken bir husustur ${ }^{48}$.

Yugoslavya, Türkiye ve Yunanistan arasındaki yakınlaşma, Trieste konusunda $^{49}$ Yugoslavya ile anlaşmazlık yaşayan İtalya'yı rahatsız etmiştir. $\mathrm{Bu}$ sebeple söz konusu devletler arasındaki diplomatik faaliyetler hususunda İtalya ile sürekli bir bilgi akışı sağlanmıştır. Bu çerçevede Dışişleri Bakanı Köprülü'nün Roma'yı resmi olarak ziyaretinin ardından, İtalya Başbakanı De Gasperi de savaş sonrasında ilk kez Yunanistan'a bir resmi ziyaret yapmıştır. Bu ziyaretlerin ana konusunu Güneydoğu Avrupa, Doğu Akdeniz ve Ortadoğu sorunları ile NATO üyeliği çerçevesinde işbirliği konuları oluşturmuştur $^{50}$. İtalyan Başbakanı yaptığı açıklamada İtalya'nın, Atlantik Paktı çerçevesinde hür dünya müdafaası tesirini arttırabilecek herhangi bir savunma Antlaşmasının lehine oldugunu söylemiştir. İtalya'nın her zaman Yugoslavya'ya el uzatmaya hazır olduğunu vurgulayan De Gasperi bunun için öncelikle aralarındaki ihtilafın adil bir şekilde çözümlenmesi gerektiğini ifade etmiştir. Aynı beyanatta De Gasperi son günlerde Türk ve Yunan devlet adamlarıyla yaptığı görüşmelerin İtalya, Yunanistan ve Türkiye'nin sıkı işbirliğinin hür dünyanın barış ve istikrarına büyük fayda getirdiğine olan inancını kuvvetlendirdiğini belirtmişti ${ }^{51}$.

İtalyan Başbakanı'nın Yunanistan ziyareti ardından Dışişleri Bakanı Köprülüi Yugoslavya'yı ziyaret etmiştir. Bu ziyaret Yugoslavya Dışişleri Bakanı tarafından dostane münasebetler tesisi yolunda iki memleketin hükümet ve milletlerin sarf ettiği gayret, anlayış ve iyi niyetin bir delili olarak nitelendirilmiştir. Dışişleri Bakanı Papoviç aynı zamanda olgunlaşan şartların ve iki memleketin müşterek emniyet ve menfaatlerine uygun işbirliğini geliştirmenin de Balkanlarda ve dünyada barışı temin için şart oldugunu söylemiştir ${ }^{52}$.

Yoğun diplomatik ziyaretler neticesinde Türkiye, Yunanistan ve Yugoslavya arasında yapılan ïçlü görüşmeler sonunda 28 Şubat 1953'te Ankara'da üç devletin Dışişleri Bakanları; Köprülü, Stefanopulos ve Popoviç arasında Dostluk ve İşbirliği Antlaşması imzalanmıştır. 10

${ }^{48}$ Türk Dış Politikası,...,s.88.

49 İkinci Dünya Savaşı sonrasında imzalanan Paris Antlaşmasıyla Trieste kenti ve çevresi Birleşmiş Milletler'in garantisi altında bağımsız, tarafsız ve askerlikten arındırılmış serbest bölge haline getirilmiştir. 1952 yılında Sovyetlerin ve Yugoslavların protestolarına karşın sivil yönetim İtalya'ya verilmiştir.Turgay Merih, Soğuk Savaşve Türkiye (1945-1960) Ankara,2006,s.45. Savas sonrası gelişneler ve İtalya'nın müttefiklerle yakınlaşmasından endişelenen Yugoslavya, İtalya'nın Trieste'yi alarak yeniden Balkanlara gelmesini önlemek için Türkiye ve Yunanistan'la işbirliği yapmak ve gücünü arttırmak istemiştir. Türk Dış Politikast..., s.589.

${ }^{50}$ Gönlübol,a.g.e.,s. 28.

${ }_{51}^{51}$ Ayın Tarihi, S.230-232, Şubat 1953,s.206-207.

${ }_{52}$ Ayın Tarihi,.., s.201 
maddeden oluşan bu anlaşma ile taraflar öncelikle Birleşmiş Milletler Antlaşması'nda beyan olunan prensiplere olan inançlarını teyit etmişlerdir. Aralarında devamlı surette işbirliği yapabilmek için ortak menfaatleri ilgilendiren bütün konular üzerinde görüşme yapmayı ve tarafların Dışişleri Bakanlarının senede bir kez ya da daha sık toplanmasını kararlaştırmışlardır. Aynı zamanda ekonomi, teknik ve kültür sahalarındaki işbirliğini geliştirmek, gerekli olduğunda teşkilatlar kurmak da antlaşmanın amaçları içerisindedir. Taraflar birbirleri aleyhine bir ittifak akdinden kaçınmayı ve her türlü anlaşmazlığı Birleşmiş Milletler Antlaşması'nda tespit edilmiş bulunan barışçı yollarla ve birbirlerinin dahili işlerine müdahaleden kaçınmayı taahhüt etmektedirler ${ }^{53}$. Antlaşmanın 8. maddesinde de NATO üyesi olan Yunanistan ve Türkiye'nin bu antlaşmadan doğacak hak ve görevlerine tesir etmeyeceği vurgulanmaktadır. Anlaşmanın sonuncu maddesi ise, antlaşmanın yürürlüğe girmesini takip eden beş yılın sonunda, taraflardan her birinin diğer taraf hükümetlere göndereceği bir beyanname ile bir yıl önceden ihbar suretiyle antlaşmaya taraf olmaktan çıkabileceği belirtilmişti ${ }^{54}$.

$\mathrm{Bu}$ antlaşma Yunan ve Yugoslav parlamentolarında oy birliği ile kabul edilirken, TBMM de anlaşmayı 18 Mayıs'ta gündeme getirmiştir. Mecliste bir konuşma yapan Dışişleri Bakanı Fuad Köprülü, söz konusu antlaşmanın Yunanistan ve Yugoslavya parlamentolarında hararetle kabul edildiğini vurgulamıştır. Anlaşma maddeleri hakkında ayrıntılı bir açıklama yapan Köprülü, antlaşmanın 8. maddesinde ifade edilen Türkiye ve Yunanistan'ın dâhil bulundukları Atlantik Paktı Antlaşması'ndan mütevellit hak ve vecibelerinin korunması ile ilgili olarak "bu hüküm gayet tabii olan hukuki vaziyetin teyidinden ibarettir" demiştir. Bu madde ile antlaşmada belirtilen işbirliği ile üyesi olunan Atlantik Antlaşması gereğince öngörülen ve tatbik edilen işbirliği arasına set çekmek gibi bir niyetin olamadığını da vurgulamıştır. Köprülü, aynı konu ile ilgili olarak::55. “...Bilakis gerek Atlantik Antlaşması Teşkilatının gerek Yugoslavya'nın muvaffakiyet ile münasip ve mümkün görünebilecek her hangi bir şekilde bu iki işbirliğinin yekdiğeri ile irtibatlandırılmasını lüzumlu görüyoruz..."diyerek aynı zamanda hükümetinin temennilerini de dile getirmiştir. Meclis huzuruna getirilen bu metnin başarılı bir imtihandan geçtiģini söyleyen Köprülü gelecekte de geçireceł̧i imtihanın aynı derecede başarılı olacağına duyduğu inancı belirtmiştir. Dostluk ve İşbirliği Antlaşması muhalefetin de büyük desteğini almış, oylamaya katılan tüm üyeler müspet oy kullanmışlardır ${ }^{56}$.

${ }^{53}$ Düstur, 3. tertip.c.34, s.1349.

${ }^{54}$ Düstur, 3. tertip, c. 34, s. 1350

55 TBMM Tutanak Dergisi, Dönem IX, c.22., Toplantı 3, 18.05.1953, s.298.
\$6 18 Mayı 1953 günü TBMM'nin 84. birleşiminde kabul edilen Dostluk ve İsirliği Andlaşması' nın tasdikine dair yapılan oylamaya katılan 327 milletvekili kabul oyu verirken 144 milletvekili oylamaya katılmamıştır. Bkz. TBMM Tutanak Dergisi,..., s.309. 
Meclisin desteğini alan bu ittifak CHP tarafından da memnuniyetle karşılanmıştır. Askeri bir antlaşma olmaması, gizli bir hükmü de bulunmadığından otomatik olarak işleyecek askeri hükümler taşımamasına rağmen üç devletin Atlantik Paktı savunma istikametinde, siyaseten ve manen bağlanması önemli bir gelişme olarak değerlendirilmiştir ${ }^{57}$. Millet Partisi de bu teşebbüsü genel olarak benimsemekle birlikte, bu antlaşmanın yalnızca manevi yardımlaşmadan ziyade siyasi ve maddi bir yardım sağlayan bir antlaşma olması hususundaki temennilerini dile getirmiştir ${ }^{58}$.

Balkanlar'daki gelişmeler ABD'nde olduğu kadar İngiliz Hükümeti tarafından da yakından takip edilmiştir. Türkiye'nin dış politikada rotasını tamamen Batı'ya çevirdiği bu dönemde Türk- İngiliz ilişkilerinin de ivme kazandığı görülmektedir. İngiliz Dışişleri tarafından Balkan Paktı öncesinde, Yugoslavya, Yunanistan ve Türkiye arasındaki diplomatik ziyaretlerin de dikkatle takip edildiği ve bu konuda raporlar yazıldığı 1 görülmüștür. Özellikle İngiliz Dışişleri Bakanı Anthony Eden'in ziyareti yoğun bir diplomasi trafiğine yol açarken gerek kamuoyu'nda gerekse hükmet çevresinde önemli bir gelişme olarak değerlendirilmiştir. İngiliz diplomatik yazışmalarında bu gezinin ayrıntıları üzerinde detaylı bilgiler verilmiştir ${ }^{59}$.

İngiliz Büyükelçiliği'nden, Londra'ya gönderilen yazışmalarda bu husus üzerinde bilgi verilmekle birlikte, Türk Hükümeti'nin Churchill'in Türkiye'ye yapacağ 1 bir ziyaret beklentisi üzerinde ayrıntılı olarak durulmuştur. Büyükelçi, Açıkalın'ın kendisine bu talebi iletirken çok ciddi ve samimi olduğuna değinmiştir. Churchill'in en içten bir şekilde karşılanacağına emin olduğunu çünkü Türkler arasında Churchill'in prestijinin çok yüksek olduğunu -şahsi bir ziyaret bile olsa- çok büyük etki yaratacağını söylemiştir. Bununla beraber Churchill'in pek fazla geziye çıkmadığını ve taç giyme töreni ile meşgul olduğunu söylediğini ancak -ne kadar samimi olduğunu bilememekle birlikte- Açıkalın'ın, kendisine Savarona Yatının gönderilebileceğini söylediğini ifade etmiştir ${ }^{60}$. Bir başka yazışmada ise, Cumhurbaşkanı Celal Bayar'ında kendisine aynı temennileri ilettiğini ve Churchill'in Yalova'da ve İstanbul'da şahsi olarak ağırlanabileceğini söylediğini anlatmaktadır. Aynı ifadeye göre Bayar, Eden'ın Nisan ayındaki ziyareti sırasında bu davet konusundan bahsedeceğini söylemiştir ${ }^{61}$. Türk Hükümetinin bu talepleri diplomatik açıdan değerlendirilmekle birlikte Kraliçe Elizabeth'in taç giyme töreni ve Churchill'in programının belirsizligi dolayısıyla Eden kendisine bu konuyu açana kadar rafa kaldırılmışıır ${ }^{62}$.




İngiltere Dışişleri Bakanı Eden'ın yapılması muhtemel ziyareti öncesinde Türk-İngiliz İlişkileri ve İngiltere'nin Türkiye'ye bakışı hakkında çeşitli konu başlıklarıyla İngiliz Dışişleri tarafından bir rapor hazırlanmıştır. Bu rapora göre Türk Politikasının o günkü rotası hakkında değerlendirmeler yapılırken mevcut zamanın İngiliz-Türk görüşmelerinin yenilenmesi için çok elverişli bir zaman olduğu vurgulanmıştır. Türk diplomasisinin son beş aydan beri yoğun bir faaliyet gösterdiğine dikkat çekilirken, Köprülü’nün Roma, Belgrat, Atina ve Paris'i ziyaretlerine değinilmiş ve Mayıs ayında Menderes'in Beyrut ve Şam'a giderek Irak kralının taht törenine katılması konusunda bilgi verilmiştir. Menderes'in çoğu geziye kendisinin gitmesine ve kendini dış ilişkilere adamasına karşılık ülke içinde tepkiler olmasına rağmen muhalefet ile uzlaşma sağlamasına dikkat çekilmektedir. Birleşmiş Milletler'in prensiplerine bağlılık, Komünizme karşı olma, endüstriyel ve tarımsal kapasiteyi geliştirme gibi unsurlar Türk Hükümetinin son faaliyetlerinde görülen olumlu amaçlar olarak değerlendirilmiştí ${ }^{63}$. NATO müttefikleri ile Yugoslavya'ya karşı askeri taahhütler meselesinde ağır ağır ilerlenmesine, Mısır ve diğer Arap illeriyle son müzakerelerindeki bazı belirsizliklere rağmen, Ekim ayından beri Türk Bakanlarının performansının oldukça sadık ve dürüst olduğu ifade edilmiştir. Yugoslavya Devlet Başkanı Tito'nun Londra ziyareti konusunda Türk Dışişleri Bakanı'na bilgi verilmesi ve Tito'nun NATO'ya katılmak hususunda istekli olmadığının duyurulması gerektiği de bu raporda yer alırken, Tito'nun Londra ziyaretinin Köprülü'ye aynı zamanda Türklerin Yugoslavya'nın tek sponsoru olmadığını ve Yugoslav barışının Batı savunmasının örüntüsüne uydurulması konusunda İngiltere ile aynı derecede aktif olduğunu göstereceği iddia edilmektedir ${ }^{64}$

Söz konusu rapor da iç siyasetteki uyuma da dikkat çekilirken İnönü ve Menderes arasındaki gerilimin ortadan kalktığ ${ }_{1}$ ve dış politika konusunda ortak hareket edildiği vurgulanmıştır. CHP ile uzlaşan DP'nin kendi radikal saflarını yok ettiği belirtilmekle beraber bu durumun özellikle Türk-Arap ilişkilerini olumsuz etkileyebileceğine dikkat çekilmiştir ${ }^{65}$. Balkan Paktı üzerinde de bir değerlendirmenin yer aldığ raporda; anlaşmanın şartlarının Yunanistan'ın ve Türkiye'nin NATO'ya vaatleri ile çelişmeyeceği ifade edilmiştir. Savaş öncesi Balkan Antantı'ndan farklı olarak bu antlaşmanın katılmak isteyen herhangi dið̧er ülkelerin (örneğin İtalya) katılımına açık olacağı belirtildikten sonra üç ülke arasındaki çift taraflı ticaret anlaşmalarının Dostluk Antlaşması ile aynı zamanda tartışıldığına dikkat çekilmektedir. Üç ülke arasındaki üç taraflı askeri tartışmaların ilkinin Ankara'da gerçekleştiği ve bu görüşmelerin yakın gelecekte de devam etmesinin muhtemel olduğu ifade edilmekte ve Trakya'nın askeri alanda

\footnotetext{
${ }^{63} F O, \ldots$, WK1051/13. p.1-2.

${ }^{64} F O \ldots$, WK 1051/13.p.3.

${ }^{65} F O, \ldots$, WK $1051 / 13$, Annex A.
} 
işbirliği için Yugoslavya, Yunanistan ve Türkiye'nin hazır oluşunun anahtarı olduğu vurgulanmaktadır. Dostluk Antlaşması için müzakereler sürdükçe Yugoslavya'nın tam askeri ittifak ümit ettiğinin netleştiği ve bunun uygulanmasının sadece Türkiye ve Yunanistan'ı değil, onların NATO'daki partnerlerini de duruma dâhil edeceği (ve 1939 Karşılıklı Yardım Antlaşması'nın iki imzası çift kez üstlenilmiş olur.) öne sürülmektedir. Söz

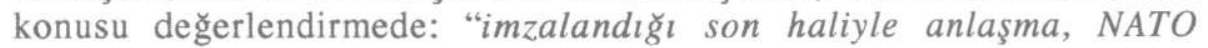
pozisyonunu yeterince muhafaza ediyor gibi gözükse de 18 Mart'ta Yunan ve Türk Sürekli Temsilcilerini Kuzey Atlantik Kuruluna tatmin edici ifadelerde bulunmasına ră̆men Türk (ve Yunan) Hükümetinin İngiliz-Birleşik Devletler-Fransa'nın beklentilerini (örneğin, Yugoslavya ile ilgili planlarinda askeri kanallarla bildirilen NATO emrine uygun davranma ve böyle planları NATO Komutanı onaylamadan imzalamamak) karşılamaya devam ettiklerinden emin olmak için onları dikkatle izlemek gerekecektir "şeklindeki ifade İngiliz Dışişleri'nin Balkan Paktı ile ilgili görüşünü göz önüne sermektedir. Aynı raporda Balkan Barışı ile sergilenen Türk Hükümetinin yapıcı planlarının İngiltere tarafından gönülden onaylandığ 1 belirtilmiş, Eden'in Türkiye ziyareti esnasında bunu tekrar etme firsatı bulabileceği vurgulanmıştır ${ }^{66}$.

Ortadoğu meselesinin de ayrıntılı olarak incelendiği raporda Türkiye'nin Arap ülkeleriyle ilişkilerini geliştirmek istemesi doğal karşılanmaktadır. Bu ilgide gerekçe olarak öncelikle Arapların Sovyet Komünizmi tarafına geçmelerinin kendi güvenliğini tehdit edeceğini bilmesi, ikinci sebep olarak da statüsünü Avrupa gücü olarak kurduğuna, Kuzey Atlantik Barış Organizasyonu'ndaki üyeliğini sağlama aldığına, Yunanistan ve Yugoslavya ile anlaştığına göre politik bağlantılarının örüntüsünü Arap illeriyle anlaşarak tamamlayabileceği fikri gösterilmektedir. Üçüncü olarak da, Ortadoğ Savunma Organizasyonu'nu oluşturma projesine ortak olmak için katılımı gerekli olan ülkelerle iyi ilişkiler geliştirmeye zorunlu olması gösterilmektedir. Türklerin Ortadogu'daki çıkarlarının İngilizlerden farklı olmadığının vurgulandığı raporda Araplarla ilişkileri geliştirme çabalarında Türkiye'nin cesaretlendirilmesi için tüm sebeplerin mevcut olduğu vurgulanmıştır ${ }^{67}$. Türkiye'nin coğrafi konumuyla, mantıken Güneydoğu Avrupa ve Ortadoğu savunmaları arasında bir köprü oluşturduğu ve NATO'ya kabulünün sağlanmasındaki ilk çıkarının Balkanların savunması olduğu belirtilmiştir. Ortadoğu'nun savunması ihtiyacı için de oldukça heyecanlı olarak tanımlanan Türkiye'nin, bölgenin stratejik "kapağı" olarak Rusya'nın Kafkaslardan petrol-üretim bölgelerine geçişini engelleyerek savunmada başlıca yardımı olabileceği belirtilmiştir ${ }^{68}$ Türk Başbakanı ve

\footnotetext{
${ }^{66} F O, \ldots .$. WK 1051/13, Annex B.

67 $F O, \ldots . .$, WK $1051 / 13$, Annex C.

${ }^{68}$ FO,...,WK 1051/13,Annex E, p.1.
} 
Dışişleri Bakanı'nın Ekim ayındaki Londra'yı ziyaretlerinde Ortadoğu savunmasında gerçekçi bir ilgi göstererek Arap ülkelerine barışçı yaklaşılması gerektig̛ini düşündüklerinden ve Irak'ın ağzını aramak için gönüllü olduklarından bahsedilmiştir. Türklerin Irak'a yaklaşmasının Iraklıların konumlarının tehlikesi konusunda aydınlatılması açısından faydası olsa da, Irak'ın Türklerle daha derin ilişkiler kurmak için isteksiz ve diğer Batı Güçleriyle birleşme haricinde onlarla ilişkilendirilmek istemeyecekleri öne sürülmüştür. Raporda; Iraklıların üzerinde daha çok Türk baskısının Ortadoğu Savunma Organizasyonu'nun gelişimi için talihsiz olabilecek ters yanita sebep olma tehlikesini doğurabileceği söylenirken, İngitere'nin Mısır'a son yaklaşımından çıkacak olası sonucu görene kadar, Ortadoğu Savunması planlarının daha çok tartışılması ile pek bir yere varılamayacağı ifade edilmiştir. Zemin için uygun koşullar sağlanmadan ve Ortadoğu savunmasında Mısır'ın katılımını garanti altına almadan İngiltere'nin Mısır'dan çekilmemekteki kararlılığını Türklerin aklına sokmak gerektiği bunun sadece İngiltere adına değil, bir bütün olarak Batının çıkarları adına önemli olduğu vurgulanmıştır ${ }^{69}$.

DP Hükümeti dış politikada Batı'ya dönük bir politika izlerken, İngiltere ile olan ilişkilerin geliştirilmesine de büyük önem vermiştir. Anthony Eden kadar aynı tarihlerde Churchill'in Türkiye'yi ziyaret etmesini sağlamak konusunda da yoğun çaba gösterilmiştir. Churchill'in muhtemel bir Türkiye ziyaretinin DP yöneticileri tarafından önemli bir prestij olarak değerlendirildiği açıktır. Ancak Churchill'in bu ziyareti gerçekleşmediği gibi Anthony Eden'ın ziyareti de sağlı sorunları nedeniyle ${ }^{70}$ ertelenecektir. Bu ziyaretin belirsiz bir tarihe ertelenmesi İngiliz Dışişleri tarafından da talihsizlik olarak değerlendirilmiş ancak Menderes ve Köprülü’nün Kraliçe Elizabeth'in taç giyme töreni için Londra'da bulundukları sırada, yoğun bir dönem olmasına rağmen Başbakan Winston Churchill tarafından ağırlanmasının arayı yumuşatacağ Haziran başında İngiltere'ye giden Menderes ve Köprülü 7 Haziran'da Türkiye'ye dönmüşlerdir ${ }^{72}$. Bu ziyaret esnasında Churchill tarafından kabul edilen Başbakan ve Dışişleri Bakanı çeşitli konularda görüş alışverişinde bulunmuşlardır. Ortadogu meselelerinin tartışıldığı bu görüşmede Menderes, Türkiye ve tüm Ortadoğu için Süveyş savunmasının hayati önem taşıdığını ve İngiltere'nin Süveyş'ten koşulsuz çekilmesinin Türkiye'yi zor duruma düşüreceğinden bahsetmiştir. Sonra bunun üçüncü bir dünya savaşının çıkmasına yol açabileceği tartışılmış, Menderes Türkiye'nin Trakya

${ }^{69} F O, \ldots$, WK 1051/13, Annex E.p.2.

${ }^{70}$ Ingiliz dışişleri Bakanı Anthony Eden'in, ticarette dahil olmak üzere çeşitli konularda görüşmek üzere 7 Nisan'da Ankara'ya geleceği basında yer almakla birlikte .Eden geçirdiği ameliyat yüzünden bu ziyareti yapamamıştır. Feroz ve Bedia Tugay Ahmad, a.g.e., s.108.

7 FO,...,WK $1051 / 17$

${ }^{72}$ Feroz ve Bedia Tugay Ahmad, a.g.e., s.110. 
cephesinde yapabileceği her şeyi yapmaya niyetli olduğunu açıklamıştır. Winston Churchill de Ruslara karşı Boğazları engellemenin önemini vurgulamış, düşmanlıklar baş gösterdiğinde Türk kıyılarını denizden gelen herhangi bir istilaya karşı savunmaya yardım etmek için İngiltere'nin denizaltıları Boğazlara göndereceğini söylemiştir. Ancak hem Boğazların iki tarafının tutulması hem de Rusların tek taraftan işgal olasılıklarında savunma önlemleri için ortak çalışma yapılması gerektiğini ifade etmiştir. Gerekli tüm teknik önlemlerin alınması için (mayınlama vs.) ortak bir çalışma olmasından bahsedilirken Rusya'daki son gelişmeler hakkında tartışılmıştır. Sovyetlerden alınan yeni bir notadan bahseden Menderes, Molotov ile girilen son iletişimde bölgesel hakları olan iki Cumhuriyetin bu haklarından çekilmeye hazırlandığını ve Türkiye'yi razı edemediğinden Rusya'nın Boğazların savunması için herhangi bir düzenleme beklemediğini belirtmiştir. Menderes bunun önemli bir gelişme olduğunu ama yine de bunun sonucunda rahatlamamak gerektiğini düşündügünü belirtmiştir. Süveyş Kanalı ile ilgili tartışmanın bir yerinde Menderes Süveyş savunması için NATO'nun sorumluluğun bir kısmını paylaşması gerektiğini söylemişti ${ }^{73}$.

Başbakan ve Dışişleri Bakanı'nın İngiltere ziyareti Türk-İngiliz ilişkileri açısından önemli bir mesafe alındı̆̆ının göstergesidir. Batı ile ilişkilerin geliştirilmesine büyük önem verildiği bu dönemde, İngiltere ve $\mathrm{ABD}$ ile yoğun diplomatik temaslar yürütülmüsştür. Bayar'ın 1954 yılının Ocak ayında başlayan ve bir ay süren $\mathrm{ABD}$ gezisi iç ve dış basında büyük ilgi ile karşılanmıştır. Bayar, ABD gezisinin ilk durağı olarak Kraliçe Elizabeth'in özel uçağı ile İngiltere'ye gitmiş ve burada gayrı resmi olarak iki gün kaldıktan sonra ${ }^{74}$ ABD'ye hareket etmiş ve $A B D$ 'de görkemli törenlerle karşılanmıştır. Senato ile Temsilciler Meclisi'nin müşterek oturumuna hitaben konuşma yapan Bayar'ın ziyaretine Amerikan basını büyük ilgi göstermiştir. Basında çıkan makalelerde Türkiye, ABD'nin en iyi ve kuvvetli müttefiki olarak nitelendirilmiştir ${ }^{75}$. Şüphesiz ki; Bayar'a gösterilen bu yoğun ilginin arkasında Kore Savaşı'nda Türk askerinin gösterdiği fedakârlık ve kahramanlığın etkisi büyüktür.

Türk siyaseti açısından 1954 yılı hem iç siyasette hem de dış siyasette oldukça hareketli bir yıl olmuştur. Nisan ayı içerisinde Mareşal Tito'nun Türkiye ziyareti geçekleşmiş ve Balkan Paktı çerçevesinde girişilen diplomatik faaliyetler devam etmiştir. Mayıs'ta yapılan genel seçimler neticesinde ise, DP oy oranını arttırarak ikinci kez iktidara gelmiştir. DP, ikinci döneminde Ortadoğu politikasına ağırlık verirken dış politikada

\footnotetext{
${ }^{73}$ FO,...,WK 1051/18, p.1-2.

${ }_{74}$ Erogul, a.g.e.s. 21 .

${ }^{75}$ Resmi Ziyaret Türkiye Cumhurreisi Celal Bayar'ın Birleşik Amerika'yı Ziyaretinin
} Hikayesi, Ocak-Mart, 1954 Ankara, Tarihsiz,s.2-5. 
gerçekleştirdiği ilk icraat ise, Balkan Paktı'nı bir ittifaka dönüştürmek olmuştur.

Üç ülke devlet adamlarının karşılıklı ziyaretleri neticesinde Yugoslavya'nın Bled kentinde 9 Ağustos 1954'te Dostluk ve İşbirliği Antlaşması imzalanmıştır. 14 maddeden ibaret olup, üç nüsha halinde Fransızca olarak kaleme alınan bu anlaşma ile taraflar dâhil olabilecekleri milletlerarası her türlü anlaşmazlığı Birleşmiş Milletler Antlaşması hükümlerine uygun olarak barış̧̧ı yolardan çözmeyi karşılıklı olarak taahhüt ediyorlardı ${ }^{76}$. Aynı zamanda içlerinden birisine ya da birine yapılacak her türlü silahlı saldırıyı bütün akit taraflara yöneltilmiş bir saldırı olarak telakki etmekle birlikte, BM Antlaşmasının 51. maddesinde tanınan münferit ve müşterek müdafaa hakkını kullanarak yardımlaşmayı da kararlaştırıyorlardı. Anlaşmanın 7. maddesi ile ise, söz konusu bu meşru müdafaa tedbirlerinden hemen BM Emniyet Konseyi'ne malumat verilmesi kararlaştırılmıştır. Yine 2. madde ile taraflar anlaşmanın söz konusu 7. maddesine zarar gelmemek koşulu ile önceden bir antlaşma hasıl olmadıkça saldırgan tarafla herhangi bir antlaşma yapmamayı taahhüt etmişlerdir. 10. madde ile ise, antlaşmanın Türkiye ve Yunanistan'ın NATO'dan doğan haklarına ve görevlerine tesir edemeyeceği vurgulanmıştır. 28 Şubat 1953 tarihli Dostluk ve İşbirliği Antlaşması'nın da Bled Antlaşması'nın hükümleriyle tadil edilmediği müddetçe yürürlükte olmasına karar verilmiştir. Yirmi senelik bir devre için akdedilen bu antlaşmanın akid taraflarca kendi anayasa kaidelerine göre tasdik edilerek yürürlüğge girmesi kararlaştırılmıştır ${ }^{77}$.

1953 yılında Ankara'da imzalanan ittifak ile taraflar, savunma tedbirleri de dahil olmak üzere güvenliklerini ilgilendiren meseleleri aralarında görüşeceklerini kararlaştırmakla birlikte tarafların birbirlerine yardım edecekleri yönünde sağlam bir taahhüt yoktu. Ancak 1954 Bled Antlaşması bir yardım anlaşması olup tarafların birbirine hangi koşullar altında yardım edecekleri antlaşmanın 2. maddesinde ifade edilmiştir. Türkiye ve Yunanistan'ın aynı zamanda NATO üyesi olması Bled Antlaşması yoluyla güvenliği sağlanmış olan Yugoslavya'yı da dolaylı bir biçimde NATO'ya yaklaştırmaktadır ${ }^{78}$.

Yunanistan, Türkiye ve Yugoslavya arasında imzalanan antlaşma Avrupa kamuoyu tarafından da memnuniyetle karşılanmıştır. Paktın, Balkanlarda olduğu kadar bütün Avrupa'da da güvenliğin esası için önemli bir unsur olacağı değerlendirmesi yapılmıştır. Fransa'da yetkili çevreler Türkiye, Yugoslavya ve Yunanistan arasında yeni bir dostluk devri açacak olan Paktı olgunluk eseri olarak nitelendirmişlerdir. İngiltere Hükümeti de

\footnotetext{
${ }^{76}$ Diustur, 3. tertip,c.36,s.287.

$\pi$ Dïstur, 3. tertip,c.36, s.287-290

78 Ayın Tarihi,..., 91.
} 
Yunanistan ve Türkiye'nin bu konuyu NATO üyesi ülkelerle istişare etmiş olmasından dolayı duydukları memnuniyeti ifade etmişlerdir. İngiltere aynı zamanda bu antlaşmayla birlikte İtalyan-Yugoslav münasebetlerinin takviyesine imkân verecek yeni gelişmelerin takip etmesini temenni etmektedir $^{79}$. Trieste meselesinin çözümlenmemesine ve ittifak öncesi görüşmelere devam edilirken gösterilen protestolara rağmen üçlü ittifak İtalyan çevrelerinde de olumlu karşılanmıştır. Paktın imzalanması Yunanistan'da da memnuniyetle değerlendirilmiş bu durumun aynı zamanda Avrupa ve milletlerarası barışı güçlendirdiği vurgulanmıştır. ABD çevreleri de gelişmeleri yakından takip etmiş, Dışişleri Bakanı Dulles anlaşmaların daha geniş bir tatbik sahası bulacağını ümit etmekle birlikte mevcut halleriyle bile Güney Avrupa'nın güvenliği için büyük önem taşıdığını söylemiştir $^{80}$. Türkiye'de de olumlu yankılar bulan Bled Antlaşması, Ankara'da dikilen tohumun yeşerip meyve vermesi olarak değerlendirilmiştir. Aynı zamanda NATO müdafaa zincirine bağlı Türkiye ve Yunanistan yanında Komünist cepheden uzaklaşan Yugoslavya'nın askeri bir pakt etrafında birleşmelerinin Komünizmin keskinleşen tehditlerine karşı önemli bir cephe olacağı öne sürülmüştür ${ }^{81}$. İttifak Antlaşması sonrası, Cumhurbaşkanı Bayar'ın Yugoslavya'yı ziyareti büyük ilgi görmüş, Cumhurbaşkanı görkemli törenlerle karşılanmıştır. Yugoslav basınında Türkiye hakkında son derece olumlu yazılar yer alırken Bayar'ın Atatürk'ün gerçekleştirdiği İstiklâl Savaşı içindeki büyük hizmetlerinden bahsedilmiştir ${ }^{82}$.

Balkan Paktı aldığı bütün olumlu tepkilere rağmen beklentileri gerçekleştirememiştir Stalin'in ölümünden sonra Sovyetler'in Yugoslavya politikasının yumuşaması ve Tito'nun tarafsızlık politikasına yönelmesi gibi sebepler Balkan Paktı'nın sonunu hazırlamışırı. Menderesin Balkan Paktını "NATO'nun Balkanlar'daki uzantısı" olarak görmesine rağmen Tito'nun en başından beri Batı'ya yakınlaşma konusunda dikkatli bir tavır sergilediğini söylemek mümkündür ${ }^{83}$. Kıbris sorunu nedeniyle Yunanistan ile ilişkilerin de bozulmaya başladığı bu dönemde ${ }^{84}$ Türkiye hem Yugoslavya hem de

${ }^{79}$ AyınTarih,i..., s.76-77.

${ }_{80}$ Aym Tarihi, ...,s.78-79.

${ }^{81}$ Aytn Tarihi,...,s.90.

${ }_{83}^{82}$ Aytn Tarihi, S.249-257, 1954, s. 59-67

${ }^{83}$ Bağc1, a.g.e.,s.58.

${ }^{84}$ 1952'de NATO'ya üye olan Türkiye ve Yunanistan arasındaki yakınlaşma, üst düzeyde yapılan karşılıklı ziyaretlerle pekiştirilmiştir. Dostluk havası 1953 yılında da devam etmiş, Kibrıs konusu giderek artan bir şekilde kamuoyunun gündemine gelmesine rağmen, ikili iliş̧kilerdeki olumlu gelişmeleri bir süre daha etkilememiştir. Türk-Yunan yakınlaşması 1930'larda olduğu gibi -bölgesel işbirliği şeklinde adeta Kıbrıs sorununun gölgesinde devam etmiştir. Bütün eleştirilere rağmen Yunanistan ile NATO içerisindeki işbirliğine, Balkan ittifakı içinde devam etmeyi arzulayan Menderes Hükümeti, Kıbrıs sorununa öncelik vermemiştir. Ancak daha önceleri konunun milli bir mesele olduğuna dair beyanlarda bulunan Papagulos'un (1953)iktidara gelmesiyle birlikte Yunanistan'da ENOSIS propagandası hız 
Yunanistan'ın olumsuz tavırlarına rağmen Balkan Paktını korumak ve devam ettirebilmek adına büyük çaba göstermiştir. Ancak Yunanistan'ın,16 Ağustos 1954'te Kıbrıs sorunu için BM'ye resmen başvurması Türk-Yunan ilişkilerini kritik bir sürece sokmuştur. Kısa bir sürede ortaya çıkan bu anlaşmazlıklar aynı zamanda devletler arasındaki ilişkilerin aslında ne kadar zayıf dayanaklar üzerine kurulduğunu gözler önüne sermektedir. ${ }^{85}$ Sovyetler'in tavizlerinin artması Yugoslavya'nın koşularının değişmesine neden olmuştur 1955 Haziranında Başbakan Bulganin ile Khrushchev'in Tito'yu ziyaret etmeleri ve Stalin'in hatalarını telafi etmeye çalışmaları Yugoslav Komünist ligi içinde olumlu karşılanırken Sovyetler'e olan hissi ve tarihi bağlılık ön plana geçmiştir. Bu ziyaret neticesinde yeni Sovyet liderlerinin dış politikadaki tutumlarının Yugoslavya'nın endişelerini yatıştırması Tito'nun Balkan paktına bakışını değiştiren önemli bir kırılma noktasıdır Türk- Yunan ilişkilerinin bozulması ise Balkan Paktına en ağır darbeyi indiren gelişme olarak değerlendirilebilir. Yugoslavya'nın Sovyetler ile iyi geçinmesi ve tarafsızlık politikası uygulaması antlaşmanın askeri yönüne son verirken, Yunanistan ile olan anlaşmazlık çok boyutlu olarak işbirliğini sona erdirmiştir ${ }^{86}$.

Balkan Paktı sürecinde Kıbrıs'ta Türklere yönelik şiddet artarak devam etmiştir. Demokrat Parti'nin İkinci döneminde Ortadoğu politikalarına ağırlık vermesi ve Bağdat Paktı'nın kurulması, Yugoslavya ile ilişkilerin daha da soğumasına neden olmuştur Yugoslavya Bağdat Paktını NATO'ya ve Güneydoğu Asya Paktı'na ilave olunan üçüncü bir harp mihrakı olarak nitelendirmiştir. Taraflar arasında kısa sürede ortaya çıkan anlaşmazlıklar yüzünden Paktın mutad toplantıları bile yapılamaz hale gelmiştir. Balkan Paktı 1960 yılında önce Yugoslav, sonra Yunan Dışişleri Bakanlıklarından yapılan açıklamalarla zımnen feshedilmiştir ${ }^{87}$.

\section{Genel Değerlendirme}

Türk siyasi hayatı içerisinde önemli bir yere sahip olan Demokrat Parti (DP) on yıllık iktidarı süresince pek çok yönüyle tartışılmıştır. Şüphesiz ki

\footnotetext{
kazanmıştır. 1954 yılında Başpiskopos Makarios , Kıbrıs'1 Yunanistan'a katmak için hummalı bir faaliyet içerisine girmiştir. 1954 yılında Kıbrıs Meselesi Türk- Yunan hükümetleri arasında resmen gündeme gelmiştir. Kıbrıs ile ilgili mitingler yapılması hususnda Menderes hükümetine yapıan baskılar artmıstır. Türk hükümetinin bütün tepkilerine rağmen, 1954 'te Yunanistan tarafından bir şikâyet konusu olarak Birleşmiş Milletler'in gündemine getirilen Kıbrıs Meselesi böylece uluslararası bir sorun haline gelmiştir. Bu tarihten itibaren Kıbrıslı Türklerin güvenliği ve hakları ciddi bir tehdit altına girmiştir. Kıbrıs sorunu Türk dıs politikası'nın en önemli konularından birisi haline gelirken Menderes Hükümeti 1955 'ten itibaren Kıbrıs konusunda daha aktif bir siyaset izlemiştir. Ayrıntılı bilgi için bkz. Türk Dış Politikası...,s.586-590.; Bağc1,a.g.e.,s.101-105. ;Uçarol,a.g.e.s.560 .; Albayrak,a.g.e.,s.426427.

${ }^{85}$ Mütercimler a.g.e.,307.

${ }^{86}$ Sander,a.g.e,s. 113-115.

${ }^{87}$ Sander,a.ge.,s.120-125.
} 
Menderes Hükümetlerinin iç siyasetteki politikaları kadar dış siyasetteki icraatları da eleştirilere hedef olmuştur. 1950 seçimleri sonrasında iktidarı CHP'den devralan DP, ilk hükümet deneyiminde dış politikada oldukça aktif bir siyaset uygulamıştır. 27 Mayısa giden süreçte Menderes Hükümetlerinin dış politikada aldıkları kararlar bugüne kadar gelen tartışmaların da başlangıcını oluşturmuştur. Bu eleştirilerin ekseninde, öncelikle DP'nin izlediği ABD yanlısı politikalar yer almaktadır. Şubat 1952'de gerçekleşen NATO üyeliği ise, şüphesiz ki Türkiye'nin geleceğini etkileyen önemli bir kırılma noktasıdır.

Demokrat Parti'nin iktidara geldiği yıllarda uyguladığı dış siyaset soğuk savaş döneminin ortaya çıkardığı atmosfer ekseninde değerlendirilmelidir. II. Dünya savaşı sonrası yıllarda Türkiye'nin Sovyet tehdidine karşı denge arayışına girdiği dönemde Türkiye'ye ilk destek ABD'den gelmiş, Misssouri gemisinin ziyareti Türk-ABD ilişkileri açısından önemli bir dönüm noktası olmuştur. Esasen CHP döneminde başlatılan Batı ile ilişkilerin geliştirilmesi ve NATO'ya üye olma misyonu Demokrat Parti tarafından büyük bir coşkuyla devam ettirilmiştir. Demokrat Parti'nin gerek parti programında gerekse de açıklanan hükümet programlanında Batı ile olan ilişkilerin daha da geliştirilmesi hususu önemle vurgulanmaktadır. Dolayısıyla oy çoğunluğuyla iktidara gelen DP dış politika konusundaki rotasını çok önceden çizmiş, bunu da sadakatle uygulamıştır.

Oldukça yoğun bir diplomasi trafiğinin yürütüldügü DP'nin ilk döneminde Kore Savaşı'na asker gönderilmesi Anayasa'ya aykırılık noktasında biçim olarak tartışılmış ancak içerik olarak çok sınırlı bir tepki görmüştür. Kore'ye asker gönderme kararı kamuoyunda büyük destek görmüştür. Ödenen bu ağır bedelin ardından gelen NATO üyeliği ise hem DP'nin prestijini arttırmış, hem de Türkiye'yi Batı'ya iyice yaklaştırmıştır. Sovyetlerden duyulan endişeye karşı ittifak ve paktlarla güvenlik arayışına giren DP Hükümeti, çıkış yolu olarak Batı ile ilişkileri mümkün olduğunca geliştirmeyi görmüşlerdir. İki kutuplu dünyada ABD'nin politikalarına paralel olarak Sovyet karşıtlığı ön plana çıkarken aynı zamanda iç siyasette DP'nin duydugu Komünizm fobisi de yöneticileri Batı'ya daha da yaklaştırmıştır. Türk dış siyasetinde bir süredir devam eden yalnızlık ve içe dönük politikalardan sonra DP'nin fazlasıyla dışa dönük bir politika uyguladığını söylemek mümkündür. NATO üyeliği'nden sonra ABD ve İngiltere'nin desteği ile Balkanlarda ve Ortadogu'da diplomatik faaliyetler yürüten Türkiye bu bölgede Paktlar oluşturmaya çalışırken bir öncü rolü oynamıştır. Türkiye'nin dış siyasetteki faaliyetleri ABD ve İngiltere tarafından yakından takip edilmiştir. Türkiye'nin NATO üyeliğine öncelikle karşı çıkan İngiltere, daha sonra ise Ortadoğu savunma sistemine katılması şartı ile onay vermiştir. Coğrafi konumu dolayısıyla İngiltere tarafından Güney Avrupa ile Ortadoğu arasında bir köprü olarak nitelendirilen Türkiye, 
aynı zamanda Sovyetlerin Kafkaslardan petrol üretim bölgelerine inmesine engel olacak stratejik bir engel olarak görülmüştür. Dolayısıyla İngiltere Ortadoğu'daki çıkarlarının korunması için Türkiye ile ilişkilerin geliştirilmesi konusuna büyük önem vermiş bu çerçevede Balkan Paktının kurulmasına destek verirken Bağdat Paktının kurulması için de yoğun teşviklerde bulunmuştur.

ABD ile yakın ilişkiler kuran DP hükümeti İngiltere ile olan münasebetleri daha da geliştirmenin yollarını aramıştır. Bu dönemde İngiliz devlet adamlarının ziyaretleri büyük önem taşırken Churchill'in Türkiye'yi ziyaret etmesi hususunda Türk Dışişleri yoģun bir diplomasi yürütmüştür. İngiltere özellikle Ortadoğu'daki çıkarları doğrultusunda Türkiye'nin Arap ülkeleri ile olan münasebetlerini yakından takip etmiştir. İngiliz arşiv belgelerinde bu dönemin Türk-İngiliz ilişkilerinin geliştirilmesi için en elverişli dönem olarak değerlendirildiği görülmektedir. Esasında Türk devlet adamları Batı ile ilişkileri geliştirmek için çaba gösterirken, İngiliz Dışişleri belgelerinin gösterdiği üzere İngiliz hükümeti de Türkiye ile ilişkileri geliştirmek üzere hassas bir diplomasi takip etmiştir. Demokrat Parti iktidarının I. Döneminde (1950-1954) devlet yöneticileri oldukça yoğun bir şekilde diş geziler yapmışlar, hatta bu noktada zaman zaman iç siyaseti "ihmal etme" suçlamalarıyla karşılaşmışlardır. Hükümet yöneticilerinin bu ziyaretleri dıs basında da ilgi ile karşılanmıştır. Bu noktada Menderes ve Köprülü'nün İngiltere, Bayar'ı ABD ve Yunanistan seyahatleri ön plana çıkmaktadır. Özellikle Bayar ABD'de gösterişli törenlerle ve büyük bir ilgi ile karşılanmıştır ki şüphesiz bu durumun ortaya çıkmasında Türk askerinin Kore'de gösterdiği üstün başarı ve fedakârlığın rolü büyüktür. Bu noktadan değerlendirildiğinde bütün olumsuzluklara rağmen Demokrat Parti iktidarının ilk dönemi dış politika açısından prestiji yüksek bir dönem olarak değerlendirilebilir. 1954 seçimlerinde DP'nin oy oranını arttırarak ikinci defa iktidar olmasında dış politikadaki bu gelişmelerin de etkisi olduğunu düşünmek mümkündür.

Yunanistan ile ilişkilerin Kıbrıs Meselesine rağmen kısa bir süreliğine de olsa düzelmesi ve iki ülke yöneticilerinin karşılıklı ziyaretleri bu dönemde ön plan çıkan önemli hadiselerdir. Türkiye Yunanistan ile anlaşarak Sovyetler ile ters düşen Yugoslavya'yı da dahil edecek bir paktın kurulması için büyük çaba göstermiştir. Dolaylı yoldan Yugoslavya'yı NATO'ya bağlayacak bu paktın kurulması konusunda Batılı devletler yoğun teşviklerde bulunmuşlar, bunu Sovyetlere karşı önemli bir güvenlik çemberi olarak değerlendirmişlerdir. Bu paktın kurulmasında aktif çaba gösteren Türkiye, Balkanlardaki özellikle Yunanistan ile yaşadığı sorunları geri planda bırakarak barışçı bir tutum sergilemiştir.

Balkan Paktı'nın Avrupa kamuoyunda yarattığ ${ }_{1}$ olumlu havaya ve Türkiye'de hissettirdiği bütün heyecana rağmen uzun vaade başarılı 
olduğunu söylemek mümkün değildir. Türkiye, Yunanistan ve Yugoslavya'nın aralarındaki geçmişten gelen anlaşmazlıklar ve rejim farklılıklarına rağmen bir araya gelmeleri umut verici girişimler olmakla beraber, iki kutuplu savaş döneminin eseri olan Balkan Paktı esasen oldukça zayıf temeller üzerine bina edilmiştir. Menderes Hükümeti de Balkan Paktı'ndan çok şey beklemiş ancak dünya siyasetinde dengelerin değişmesi ve farklı dinamiklerin ortaya çıkması ile birlikte bu beklenti hayal kırıklığına dönüşmüştür. Türk hükümetinin bütün iyi niyetleriyle bu süreçte rafa kaldırdığ 1 Türk-Yunan anlaşmazlığı Kıbrıs meselesi yüzünden tekrar gündeme gelmiş ve Yunanistan ile ilişkiler alabildiğine gerginleşmiştir. Özellikle 6-7 Eylül olayları ile birlikte iyice keskinleşen münasebetler hem Balkan Paktı'nın geleceğini olumsuz etkilemiş, hem de bu tarihten sonra anlaşmazlık gittikçe çözümsüz bir hal almıştır.

DP'nin bu ilk döneminde göze çarpan bir diğer husus ise DP ve ana muhalefet partisi CHP arasında dış politika konusundaki uyumdur. Genel olarak değerlendirildiğinde DP iktidarının dışs siyasetteki uygulamaları çok fazla eleştiriye uğramamıştır. NATO üyeliği ve Balkan Paktı, muhalefet ve kamuoyu tarafından da kabul görmüş ve memnuniyet ile karşılanmıştır. İsmet Paşa dış siyasetteki gelişmeleri dikkatle takip etmiş, Balkan Paktı'nın başarısız olmasından duyduğu endişelere rağmen hadiseleri ülke menfaatleri ekseninde değerlendirerek bu konuda aktif bir muhalefet yapmamıştır. İktidar ve muhalefet arasındaki bu uyum İngiliz arşiv belgelerinde de dikkat çekici bir gelişme olarak ifade edilmektedir.

\section{KAYNAKÇA}

Ahmad, Feroz ve Bedia Tugay: Türkiye'de Çok Partili Politikanın Açıklamalı Kronolojisi 1945-1971, İstanbul, 1976.

Armaoğlu, Fahir: 20. Yüzyll Siyasi Tarihi (1914-1980), Ankara, 1993.

Albayrak, Mustafa: Türk Siyasi Hayatında Demokrat Parti (1946-1960), Ankara, 2004.

Ayın Tarihi: S.230-232, 1953.

Ayın Tarihi: S.249-257, 1954.

Bağcı, Hüseyin: DP Dönemi Dış Politikası, Ankara, 1990.

Birand, Mehmet Ali, C. Dündar ve B. Çaplı: Demirkırat Bir Demokrasinin Doğuşu, İstanbul, 2007.

Cumhuriyet: 6 Nisan 1946.

Celal Bayar'ın Söylev ve Demeşleri 1933-1955, İstanbul, 1999. 
Çavdar, Tevfik: Türkiye'nin Demokrasi Tarihi, Ankara, s. 2004.

Düstur, 3. tertip, c. 34.

Dïstur, 3. tertip, c. 36.

DP Tüzük ve Program, Ankara, 1949.

Ekincikli, Mustafa: Türk Dış Siyaseti İnönü-Bayar Dönemleri, Ankara, 2007.

Eroğul, Cem: DP Tarihi ve İdeolojisi, Ankara, 2003.

Foreign Office, 371/ 107555/ WK1051/1, 31.12. 1952.

FO,...,WK1051/4, 21.01.1953.

FO,..., WK1051/4 12.02. 1953.

$F O, \ldots$, WK1051/4 5.03.1953.

$F O, \ldots$, WK1051/13.

FO,...,WK1051/13, Annex A.

FO,..., WK1051/13, Annex B.

$F O, \ldots$, WK1051/13, Annex C.

$F O, \ldots$, WK1051/13,Annex E.

FO,...,WK1051/13, Annex E.

FO,...,WK1051/17.

FO, ...,WK1051/18.

Geçiş Sürecinde Türkiye (Der. Irvin C. Schick, E. Ahmet Tonak), İstanbul, 2003.s.122.

Gönlübol, Mehmet vd. (kolektif eser): Olaylarla Türk Dış Politikast (1919-1990), Ankara, 1993.

Hükümetin Programl (30.03.1951), Ankara, 1951.

Merih, Turgay: Soğuk Savaş ve Türkiye (1945-1960), Ankara, 2006k

Mütercimler, Erol, Mim Kemal Öke: Düşler ve Entrikalar-DP Dönemi Türk Dış Politikast, İstanbul, 2004.

Öztürk, Kazım: Türkiye Cumhuriyeti Hükümetleri ve Programları, İstanbul, 1968.

Uçarol, Rıfat: Siyasi Tarih, İstanbul, 1985.

Resmi Ziyaret Türkiye Cumhurreisi Celal Bayar'ın Birleşik Amerika'yı Ziyaretinin Hikayesi, Ocak-Mart, 1954 Ankara, Tarihsiz, s.2-5. 
Saray, Mehmet: Sovyet Tehdidi Karşısında Türkiye'nin NATO'ya Girişi III. Cumhurbaşkanı Celal Bayar'ın Hatıraları ve Belgeler, Ankara, 2000.

Sander, Oral: Balkan Gelişmeleri ve Türkiye (1945-1965), Ankara, 1969, s.85.

Sükan, Faruk: Başbakan Adnan Menderes'in Meclis Konuşmaları, TBMM 19501960 .

Türk Dış Politikası, Kurtuluş Savaşından Bugüne Olgular, Belgeler, Yorumlar 1919. 1980 (Edt. Baskın Oran) c.1 İstanbul, 2003.

TBMM Tutanak Dergisi, Dönem IX, c.3, 11.12.1950.

TBMM Tutanak Dergisi, Dönem IX, c.22., 18.05.1953.

Yalçın, E.Semih: Atatürk'ün Milli DışS Siyaseti, Ankara, 2000, s.225-226. 